\title{
ANALISIS PENGELOLAAN SISTEM SURAT MENYURAT DENGAN SISTEM MANUAL DAN SISTEM NOTA DINAS ONLINE DALAM UPAYA MENINGKATKAN PENGENDALIAN SURAT PADA PT ANEKA TAMBANG (PERSERO) TBK. - UNIT GEOMIN
}

\author{
Ahlan Novia Garnasih ${ }^{1}$, Tuti Hartati ${ }^{2}$ dan Menik Wijiyanty ${ }^{3}$ \\ ${ }_{1,2,3}$ Administrasi Bisnis Terapan, Politeknik Negeri Jakarta \\ Email : ${ }^{1}$ ahlannovia@gmail.com
}

\begin{abstract}
This research aims to know the effort to improve the control of letters in mail handling by using manual system and online service note system at PT Aneka Tambang (Persero) Tbk. - Unit Geomin. The research method used in this research is qualitative research method. The research informants consisted of key informants and supporter informants. The key informant in this research is Secretariat of Unit Geomin centered on HC, CSR, and GA, while the supporter informants is Work Unit Administration. After that, data collection techniques use interview, observation, and document. Data analysis technique used in this research is Miles and Huberman Model which consist of data reduction, display data, and conclusion. The results of the research indicate that: (a) Upgrading the control of letters in mail handling by using manual system in Unit Geomin consist of: evaluating SOP or procedure of mail handling by manual system, applying electronic signatures to bosses who are not in the office because official travel or furlough, and improve the control of the letter with the manual system in the future to be used as mail handling with the online system, (b) Upgrading the control of letters in mail handling by using online service note system in Unit Geomin consist of: improving the performance of ICT continuously to be able to maintenance internet network, access addition, and maintenance more quickly and do not interfere with employees who are working.
\end{abstract}

Key words: Letter, Mail Handling, Control of Letter.

\begin{abstract}
Abstrak
Penelitian ini bertujuan untuk mengetahui upaya yang dapat dilakukan untuk meningkatkan pengendalian surat dalam pengelolaan surat masuk dan surat keluar dengan menggunakan sistem manual dan sistem nota dinas online pada PT Aneka Tambang (Persero) Tbk. - Unit Geomin. Metode penelitian yang digunakan dalam penelitian ini adalah metode penelitian kualitatif. Informan penelitian dalam penelitian ini terbagi menjadi dua yaitu: informan kunci dan informan pendukung. Adapun informan kunci dalam penelitian ini yaitu Sekretariat Unit Geomin yang berpusat pada Satuan Kerja HC, CSR, dan GA, sedangkan informan pendukung yaitu Administrasi Satuan Kerja Unit Geomin. Selanjutnya, pengumpulan data menggunakan teknik wawancara, observasi, dan dokumen. Teknik analisis data yang digunakan dalam penelitian ini adalah Model Miles dan Huberman yang terdiri dari tahapan-tahapan yaitu: reduksi data, penyajian atau display data, dan kesimpulan atau verifikasi. Hasil penelitian menunjukkan bahwa: (a) Peningkatan pengendalian surat dalam pengelolaan surat dengan sistem manual di Unit Geomin dapat dilakukan dengan cara seperti: evaluasi SOP atau prosedur pengelolaan surat dengan sistem manual, menerapkan tanda tangan elektronik untuk atasan yang tidak sedang ada di kantor karena keperluan perjalanan dinas atau cuti yang sangat lama, dan meningkatan pengendalian surat dengan sistem manual kedepannya untuk dapat dijadikan sebagai pengelolaan surat dengan sistem online, (b) Peningkatan pengendalian surat dalam pengelolaan surat dengan sistem nota dinas online di Unit Geomin dapat dilakukan dalam beberapa hal yaitu: meningkatkan kinerja ICT secara terus-menerus supaya dapat melakukan maintenance jaringan internet, penambahan akses nota dinas online, serta maintenance dengan lebih cepat dan tidak menggangu para karyawan yang sedang bekerja.
\end{abstract}

Kata kunci: Surat, Pengelolaan Surat, Pengendalian Surat. 


\section{PENDAHULUAN}

Setiap perusahaan yang baik pasti memiliki prosedur pengelolaan surat menyurat. Pengelolaan surat menyurat yang baik dapat membantu sekretaris dalam mengelola hingga mengarsipkan surat sesuai dengan sistem yang diterapkan oleh perusahaan. Dengan adanya pengelolaan surat menyurat dalam perusahaan dapat membuat surat masuk dan surat keluar menjadi lebih terstruktur.

Berkaitan dengan hal di atas terkait pengelolaan surat menyurat juga telah diterapkan oleh salah satu perusahaan yaitu PT Aneka Tambang (Persero) Tbk. - Unit Geomin. Dalam mengelola surat menyurat, Unit Geomin dibantu oleh satuan kerja HC, CSR dan GA karena tidak memiliki Sekretaris General Manager sehingga kegiatan sekretariat dipusatkan pada satuan kerja HC, CSR, dan GA.

Unit Geomin pada umumnya dalam mengelola surat masuk dan surat keluar yakni telah menerapkan dua sistem yaitu: sistem manual dan sistem nota dinas online.

Meskipun Unit Geomin telah mengelola surat dengan sistem manual dan sistem nota dinas online, tetapi berbagai masalah masih dapat ditemukan. Masalah tersebut meliputi: 1) pengelola surat masuk baik dalam sistem manual maupun sistem nota dinas online masalah yang ditemukan yakni pendistribusian surat masuk terkadang masih tidak sesuai prosedur, 2) pengelolaan surat keluar dimana penomoran surat keluar dengan sistem manual pada nomor urut surat sering kali ganda/double dikarenakan pembuatan surat yang back date, 3) pengiriman surat keluar dengan sistem manual kadang kala tidak menggunakan buku ekspedisi atau surat pengantar, 4) pembuatan nota dinas seringkali terhambat karena terkendala jaringan internet yang error, sehingga aplikasi nota dinas online dalam website antam portal tidak dapat diakses.

Dari berbagai masalah yang telah diungkapkan di atas, maka perlu dilakukan upaya meningkatkan pengendalian surat untuk membenahi masalah-masalah yang terjadi dalam pengelolaan surat, supaya kegiatan surat menyurat dapat dikelola dengan lebih baik lagi.

Berdasarkan hal-hal di atas, penulis ingin menggali secara mendalam mengenai upaya meningkatkan pengawasan atau pengendalian surat dalam pengelolaan surat dengan sistem manual dan sistem nota dinas online. Atas latar belakang tersebut, maka penulis tertarik untuk mengambil judul penelitian skripsi dengan judul "Analisis Pengelolaan Sistem Surat Menyurat dengan Sistem Manual dan Sistem Nota Dinas Online dalam Upaya Meningkatkan Pengendalian Surat pada PT Aneka Tambang (Persero) Tbk. - Unit Geomin”.

\section{Rumusan Masalah}

1. Bagaimana upaya yang dapat dilakukan untuk meningkatkan pengawasan atau pengendalian surat dalam pengelolaan surat masuk dan surat keluar dengan menggunakan sistem manual pada PT Aneka Tambang (Persero) Tbk. - Unit Geomin?

2. Bagaimana upaya yang dapat dilakukan untuk meningkatkan pengawasan atau pengendalian surat dalam pengelolaan surat masuk dan surat keluar dengan menggunakan sistem nota dinas online pada PT Aneka Tambang (Persero) Tbk. - Unit Geomin?

\section{Tinjauan Pustaka}

\section{Pengelolaan Surat Masuk}

Sedianingsih dkk. (2014:85-86) menyatakan prosedur pengurusan surat masuk meliputi hal-hal berikut:

1. Menyortir/memisahkan.

2. Membuka surat.

3. Mengeluarkan dan memeriksa isi surat.

4. Pencatatan surat.

5. Membaca dan memberi catatan.

6. Pimpinan perusahaan lebih suka apabila surat masuk tidak diberi coret-coretan.

7. Menyampaikan surat kepada pimpinan. 
8. Distribusi (disposisi) surat ke departemen lain.

9. Menjawab surat pada waktu pimpinan tidak ada di tempat.

\section{Pengelolaan Surat Keluar}

Sedianingsih dkk. (2014:89-91) menyebutkan terkait pemrosesan surat keluar meliputi hal-hal berikut:

1. Menerima pendiktean atau konsep tertulis dari pimpinan dengan mendapatkan tanda tangan pimpinan atau point-point yang diberikan pimpinan.

2. Mencatat pada Buku Agenda atau Kartu Kendali.

3. Mengetik konsep surat - bentuk akhir.

4. Meminta tanda tangan kepada pimpinan.

5. Mengecek surat yang akan dikirim.

6. Mendistribusikan surat.

\section{Pengendalian Surat}

Pengendalian surat dapat memberikan manfaat jika diterapkan untuk meningkatkan pengelolaan surat yang lebih baik. Menurut Ummah (2017) manfaat pengendalian surat terdiri dari:

1. Surat akan tercatat dengan baik.

2. Prosedur penanganan surat jelas.

3. Surat akan tersimpan baik sehingga mudah untuk ditemukan.

4. Rahasia akan terjaga.

Selain itu, jika pengendalian surat tidak diterapkan untuk pengelolaan surat maka akan mendatangkan kerugian, menurut Ummah (2017) kerugian tersebut diantaranya sebagai berikut:

1. Surat dan informasinya bisa hilang.

2. Kantor menjadi tidak rapi karena banyak tumpukan kertas yang tidak tertata.

3. Surat sulit ditemukan jika dicari karena letaknya tidak disusun dengan teratur.
HASIL DAN PEMBAHASAN

\section{Hasil Analisis}

Analisis Kondisi Fisik (Tempat) dan Fasilitas

\section{a. Kondisi Fisik (Tempat)}

Kondisi kantor bagi sekretariat pusat dan administrasi satuan kerja untuk mengelola surat menyurat yakni sangat terbuka, karena tidak ada ruangan tertutup untuk sekretariat pusat dan administrasi satuan kerja dalam mengelola surat.

\section{b. Fasilitas Kantor Unit Geomin PT Aneka Tambang (Persero) Tbk.}

Semua administrasi satuan kerja dan sekretariat pusat memiliki fasilitas yang sama dalam pengelolaan surat dengan sistem manual yaitu: ATK, personal computer, printer, dan lain-lain. Sedangkan fasilitas yang digunakan untuk mengelola surat dengan sistem nota dinas online yaitu: personal computer, jaringan internet, akses yang terdaftar. (Sekretariat Pusat, 25 Mei 2018)

\section{Petugas Pengelola Surat}

\section{a. Latar belakang pendidikan kesekretariatan atau administrasi}

Administrasi satuan kerja dan sekretariat pusat yang tidak memiliki latar belakang pendidikan maupun wawasan kesekretariatan, pekerja hanya diberikan pelatihan dan itupun sangat jarang dilakukan. Seluruh administrasi satuan kerja dan sekretariat pusat lebih sering hanya berpedoman pada buku Pedoman Tata Persuratan Dinas dan Kearsipan PT ANTAM Tbk. Hal tersebut dikarenakan kegiatan surat menyurat di Unit Geomin dianggap sederhana.

\section{b. Pelatihan kesekretariatan khususnya dalam pengelolaan surat}

Petugas pengelola surat khususnya sekretariat pusat pernah melakukan pelatihan kesekretariatan tetapi hal tersebut jarang dilakukan. Sedangkan administrasi satuan kerja belum tentu atau tidak mendapat pelatihan kesekretariatan. Salah satu pelatihan yang pernah 
dilaksanakan oleh petugas pengelola surat yaitu Unit Geomin pernah diberikan training oleh kantor pusat untuk mempelajari bagaimana cara penggunaan sistem nota dinas online.

\section{c. Kebutuhan SDM sebagai petugas pengelola surat}

Unit Geomin memiliki 1 orang SDM pada sekretariat pusat dan seluruh administrasi satuan kerja, karena Unit Geomin merupakan unit yang kecil sehingga lingkup aktivitasnya tidak besar. Tetapi untuk satuan kerja Exploration Mining and Development (EMD) merupakan satuan kerja yang besar di Unit Geomin sehingga tidak cukup hanya 1 orang SDM yang menjadi administrasi satuan kerja.

\section{d. Keterampilan pegawai dalam mengelola surat}

Keterampilan sekretariat pusat dan adminstrasi satuan kerja cukup baik dan cukup memahami dalam mengelola surat meskipun terdakang terjadi suatu hambatan dalam mengelola surat menyurat. (Observasi, 25 Mei 2018)

\section{Pengelolaan Surat dengan Sistem Manual}

a. Pedoman pengelolaan surat dengan sistem manual

Unit Geomin PT Aneka Tambang (Persero) Tbk. memiliki buku pedoman untuk pengelolaan surat dengan sistem manual yaitu Pedoman Tata Persuratan Dinas dan Kearsipan PT ANTAM Tbk.

Pengelolaan surat dengan sistem manual sudah sesuai dengan Pedoman Tata Persuratan Dinas dan Arsip PT ANTAM Tbk. tetapi pengelolaan surat di Unit Geomin telah mengalami perkembangan karena telah menerapkan beberapa sistem untuk pengelolaan surat yang lebih maju. (Observasi, 25 Mei 2018) b. Pembagian tugas pengelolaan surat dengan sistem manual yang dilakukan oleh sekretariat pusat dan administrasi satuan kerja

Tugas dan tanggung jawab sekretariat pusat yaitu mempusatkan permintaan nomor surat, kode masalah, kode satuan kerja, pengelolaan surat masuk, arsip surat, dan tertib administrasi surat. Sedangkan tugas dan tanggung jawab administrasi satuan kerja hanya mengelola surat menyurat untuk satuan kerjanya sendiri dan penandatanganan surat biasanya dilakukan oleh manajer satuan kerja atau vice president satuan kerja tersebut. (Sekretariat pusat dan administrasi satuan kerja, 25dan 31 Mei 2018)

\section{c. Fasilitas yang digunakan dalam mengelola surat dengan sistem manual}

Fasilitas yang untuk mengelola surat dengan sistem manual yaitu: ATK, personal computer, printer, mesin fotocopy, mesin penghancur kertas, map, dan ordner.

\section{d. Ketentuan Persuratan Dinas PT} Aneka Tambang (Persero) Tbk.

PT Aneka Tambang (Persero) Tbk. telah menerapkan keseluruh unit dan unit bisnis termasuk Unit Geomin bahwa surat yang diterapkan dalam perusahaan berupa surat dinas.

Berdasarkan Pedoman Tata Persuratan dan Kearsipan (2009:2-7) bentuk surat dinas dapat digolongkan menjadi dua jenis, yaitu: menurut bentuk penuangan dan sifat.

a. Bentuk surat menurut penuangan: surat dinas pengatur (produk hukum), surat dinas tidak mengatur (surat biasa), dan surat dinas bentuk khusus.

b. Bentuk surat menurut sifat: keaslian surat, bobot informasi surat, pengamanan informasi surat, dan penyampaian surat. 


\section{e. Pengelolaan surat dengan sistem manual}

Pengelolaan surat dengan sistem manual dibedakan menjadi pengelolaan surat masuk dan pengelolaan surat keluar.

\section{Pengelolaan surat masuk dengan sistem manual}

Berikut ini merupakan prosedur pengelolaan surat masuk dengan sistem manual yang berlaku di Unit Geomin PT Aneka Tambang (Persero) Tbk.

a) Penerimaan surat.

b) Penyortiran/seleksi surat.

c) Membuka surat.

d) Mencatat surat pada buku agenda surat masuk.

e) Pemberian lembar kendali.

f) Menyerahkan surat kepada General Manager.

g) Menginput ke program Microsoft Access sebagai sistem pencatatan terkomputerisasi.

h) Penerusan atau pendistribusian.

i) Arsip surat.

\section{Pengelolaan surat keluar dengan sistem manual}

Surat keluar yang diterapkan pada Unit Geomin PT Aneka Tambang (Persero) Tbk. yakni terbagi menjadi tiga bagian yaitu: surat dinas pengatur (produk hukum), surat dinas tidak mengatur (surat biasa), dan surat sangat rahasia/rahasia/terbatas.

Berikut ini merupakan prosedur pengelolaan surat keluar dengan sistem manual yang berlaku di Unit Geomin PT Aneka Tambang (Persero) Tbk.

a) Pembuatan konsep surat.

b) Pemberian nomor surat.

c) Mencatat pada buku agenda surat keluar.

d) Meminta tanda tangan kepada pimpinan yang bersangkutan sesuai dengan Kode Jabatan pada nomor surat.

e) Membubuhkan cap.

f) Menginput ke program Microsoft Access sebagai sistem pencatatan terkomputerisasi. g) Mengecek surat yang akan dikirim atau didistribusikan.

h) Mengirim atau mendistribusikan surat.

i) Arsip surat.

Masalah terjadi dalam melakukan pengelelolaan surat dengan sistem manual

Masalah-masalah yang ditemukan yakni sebagai berikut:

1) Pencatatan surat hanya dilakukan di sekretariat pusat sehingga administrasi satuan kerja tidak memiliki pencatatan surat. Bagi administrasi satuan kerja menyulitkan jika pencatatan surat secara terpusat, karena tidak praktis untuk melakukan pencarian surat dimana administrasi satuan kerja harus ke sekretariat pusat untuk melihat pencatatan surat untuk mencari arsip.

2) Administrasi satuan kerja membuat konsep surat kemudian tidak memberikan hard copy atau soft copy kepada sekretariat pusat. Hal tersebut menyebabkan arsip di sekretariat pusat tidak lengkap, karena pengarsipan surat juga dibuat secara terpusat di sekretariat pusat. Tetapi administrasi satuan kerja juga melakukan pengarsipan hanya untuk kepentingan yang berkaitan satuan kerja bukan seluruh Unit Geomin.

3) Arsip surat yang tidak lengkap karena terdapat surat hilang dimana belum sempat di scan atau di fotocopy tetapi sudah dikirim kepada pihak penerima, dan surat yang tidak diterima oleh administrasi satuan kerja karena dalam proses dibaca oleh vice president atau manajer satuan kerja hingga surat hilang sebelum diberikan ke administrasi satuan kerja.

4) Berkaitan dengan masalah waktu, untuk surat masuk general manager lama memberikan disposisi sehingga kinerja sekretariat pusat lama untuk mendistribusikan ke satuan kerja, padahal surat tersebut membutuhkan tindak lanjut yang cepat. Sedangkan 
untuk surat keluar lama untuk persetujuan atau tanda tangan.

5) Sistem pendistribusian surat dengan email terhambat jika inbox penerima surat penuh. Unit Geomin menerapkan program Microsoft Outlook, untuk penggunaan email untuk aktivitas sehari-hari.

6) Personal computer yang dimiliki oleh sekretariat pusat mengalami loading yang lama, sehingga mengganggu saat proses bekerja. Tetapi hal tersebut tidak dialami oleh para administrasi satuan kerja.

7) Satuan kerja Exploration Mining and Development mengalami kekurangan tenaga kerja pengelola surat karena satuan kerja tersebut merupakan satuan kerja besar yang membawahi 5 divisi didalamnya, sedangkan yang menjadi administrasi satuan kerja hanya satu orang saja seperti administrasi satuan kerja lainnya.

\section{Upaya untuk meningkatkan pengendalian dalam pengelolaan surat dengan sistem manual}

1. Upaya yang dilakukan untuk mengatasi masalah yang terjadi pada pengelolaan surat dengan sistem manual

Beberapa upaya yang dapat dilakukan untuk mengatasi masalah yang terjadi pada pengelolaan surat dengan sistem manual yakni sebagai berikut:

a) Supaya adminitrasi satuan kerja dapat menerapkan pencatatan surat dan sekretariat pusat maupun administrasi satuan kerja sama-sama memiliki hard copy untuk penyimpanan surat sehingga penyimpanan surat menjadi lengkap, maka sebaiknya sekretariat pusat melakukan pembaruan SOP pengelolaan surat yang menyeluruh hingga administrasi satuan kerja supaya pengelolaan surat dapat dilakukan dengan lebih baik lagi.

b) Selanjutnya, untuk kasus surat hilang karena belum sempat di fotocopy ataupun di scanning tetapi sudah terlanjur dikirim kepada penerima, hal ini dapat diatasi dengan menghubungi ke pihak penerima yang bersangkutan untuk diminta melakukan pengiriman surat kembali biasanya melalui email.

c) Terkait masalah surat yang lama mendapat disposisi sehingga mempengaruhi distribusi surat, surat yang lama mendapatkan tanda tangan, dan email penerima surat penuh hal tersebut dapat diatasi dengan mengkonfirmasikan kepada pihak yang bersangkutan melalui chat whatsapp atau media lainnya.

d) Dalam mengatasi sistem pendistribusian surat dengan email yang terhambat jika inbox penerima surat penuh, hal tersebut dapat diatasi dengan mengkonfirmasikan kepada pihak yang bersangkutan melalui chat whatsapp atau media lainnya.

e) Fasilitas personal computer yang dimiliki oleh sekretariat pusat mengalami loading yang lama, hal tersebut dapat diatasi dengan meminta bantuan kepada ICT untuk dilakukan maintenance berkelanjutan supaya menghindari keadaan loading yang lama secara terus menerus.

f) Untuk mengatasi kekurangan tenaga kerja pengelola surat pada satuan kerja Exploration Mining and Development, hal tersebut dapat diatasi dengan membuat nota dinas online perihal permohonan penambahan tenaga kerja administrasi satuan kerja Exploration Mining and Development ke satuan kerja HC, CSR, General Affairs yang telah disetujui oleh Vice President satuan kerja Exploration Mining and Development dan telah diketahui oleh General Manager Unit Geomin.

\section{Peningkatan pengendalian surat dengan sistem manual}

Beberapa upaya yang dapat dilakukan untuk meningkatkan pengendalian surat dengan sistem manual yakni sebagai berikut: 
a) Evaluasi SOP atau prosedur pengelolaan surat dengan sistem manual, supaya dapat menjangkau pengelolaan surat di satuan kerja. Sehingga output yang didapat yaitu distribusi surat jelas dan pencatatan surat jelas.

b) Selanjutnya diharapkan Unit Geomin dapat menerapkan tanda tangan elektronik untuk atasan kedepannya supaya memudahkan administrasi satuan kerja dan sekretariat pusat pada proses tanda tangan jika atasan tidak ada ditempat / kantor.

c) Peningkatan pengendalian surat dengan sistem manual kedepannya lebih dilakukan menjadi sistem online, karena jika ditinjau dari sistem pencatatan surat dengan menggunakan program Microsoft Access hal tersebut aksesnya hanya dimiliki oleh sekretariat pusat, sedangkan jika diterapkan menjadi sistem online semua satuan kerja dapat melihat terkait pencatatan surat.

\section{Pengelolaan Surat dengan Sistem Nota} Dinas Online

a. Pedoman pengelolaan surat dengan sistem nota dinas online

Terdapat pedoman nota dinas online yang dibuat oleh PT Aneka Tambang (Persero) Tbk., tetapi tidak di share kepada Unit. Unit hanya diberikan training oleh kantor pusat untuk mempelajari bagaimana cara penggunaan sistem nota dinas online.

b. Pembagian tugas pengelolaan surat dengan sistem nota dinas online yang dilakukan oleh sekretariat pusat dan administrasi satuan kerja

Sekretariat pusat bertanggung jawab untuk mengelola nota dinas online untuk seluruh Unit Geomin dan administrasi satuan kerja bertanggung jawab mengelola nota dinas online untuk satuan kerjanya sendiri, dari mulai pembuatan konsep hingga persetujuan oleh vice president atau manajer satuan kerja, karena akses yang dimiliki sesuai dengan satuan kerjanya. (Sekretariat pusat dan administrasi satuan kerja, 25dan 31 Mei 2018)

c. Fasilitas yang digunakan dalam mengelola surat dengan sistem nota dinas online

Fasilitas yang digunakan untuk mengelola surat dengan sistem nota dinas online yaitu: personal computer, jaringan internet dan akses yang terdaftar.

\section{d. Pengelolaan surat dengan sistem nota dinas online}

Pengelolaan surat dengan sistem nota dinas online dibedakan menjadi pengelolaan nota dinas masuk dan pengelolaan nota dinas keluar.

\section{Pengelolaan surat masuk dengan sistem nota dinas online}

Berikut ini merupakan prosedur pengelolaan surat masuk dengan sistem nota dinas online yang diterapkan di Unit Geomin PT Aneka Tambang (Persero) Tbk.

a) Penerimaan surat.

b) Penyortiran/seleksi surat.

c) Mencatat surat pada buku agenda surat masuk.

d) Pemberian lembar kendali.

e) Menyerahkan surat kepada General Manager.

f) Menginput ke program Microsoft Access sebagai sistem pencatatan terkomputerisasi.

g) Penerusan atau pendistribusian.

h) Arsip surat.

\section{Pengelolaan surat keluar dengan sistem nota dinas online}

Berikut ini merupakan prosedur pengelolaan surat keluar dengan sistem nota dinas online yang diterapkan di Unit Geomin PT Aneka Tambang (Persero) Tbk.

a) Pembuatan konsep surat.

b) Pemberian nomor surat. 
c) Proses persetujuan (approval) oleh general manager.

d) Mengecek nota dinas yang akan dikirim.

e) Mengirim nota dinas kepada sekretariat.

Masalah yang terjadi dalam melakukan pengelolaan surat dengan sistem nota dinas online

Masalah-masalah yang ditemukan yakni sebagai berikut:

1) Proses persetujuan (approval) yang memakan waktu lama, karena pada tahap ini diperlukan review oleh atasan apakah nota dinas tersebut sudah sesuai atau belum sesuai. Jika sudah sesuai maka akan disetujui (approved), tetapi jika tidak sesuai maka atasan dapat langsung mengedit nota dinas tersebut atau jika atasan sibuk maka nota dinas langsung dikembalikan kepada yang membuat konsep surat untuk di revisi.

2) Jaringan internet kadangkala mengalami kendala.

3) Tidak semua administrasi satuan kerja memiliki akses nota dinas online.

Upaya untuk meningkatkan pengendalian dalam pengelolaan surat dengan sistem nota dinas online

1. Upaya yang dilakukan untuk mengatasi masalah yang terjadi pada pengelolaan surat dengan sistem nota dinas online

Beberapa upaya yang dapat dilakukan untuk mengatasi masalah yang terjadi pada pengelolaan surat dengan sistem nota dinas online yakni sebagai berikut:

a) Masalah proses persetujuan (approval) dapat diatasi dengan koordinasi atau sosialisasi kepada general manager dengan melalui chat whatsapp atau media lainnya.

b) Masalah jaringan internet dapat diatasi dengan meningkatkan kinerja ICT untuk mengelola maintenance yang tidak mengganggu karyawan bekerja dan lebih baik lagi kedepannya, karena kendala jaringan internet mayoritas disebabkan oleh maintenance internet dan berbagai situs Aneka Tambang yang dilakukan oleh ICT, sehingga membuat karyawan terganggu pada saat bekerja.

c) Pihak ICT seharusnya dapat menambah akses sistem nota dinas online kepada administrasi satuan kerja lainnya, sehingga akses nota dinas tidak hanya dimiliki oleh 3 orang saja yaitu: sekretariat pusat, administrasi satuan kerja Quality Management Assurance (QMA), dan administrasi satuan kerja Exploration Mining and Development (EMD).

\section{Peningkatan pengendalian surat} dengan sistem nota dinas online

Beberapa upaya yang dapat dilakukan untuk meningkatkan pengendalian surat dengan sistem nota dinas online supaya pengelolaan surat dalam jangka panjang menjadi lebih maju lagi yakni dapat dilakukan dengan cara yaitu: meningkatkan kinerja ICT secara terusmenerus supaya dapat melakukan maintenance jaringan internet, penambahan akses nota dinas online, serta maintenance dengan lebih cepat dan tidak menggangu para karyawan yang sedang bekerja. Hal tersebut disebabkan karena sistem nota dinas online sangat tergantung pada jaringan internet dan akses yang dimiliki pegawai supaya dapat mengelola nota dinas.

\section{Pembahasan}

Peningkatan pengendalian surat di Unit Geomin baru akan diterapkan sehingga dapat dikatakan masih perencanaan dalam jangka panjang. Berikut ini merupakan beberapa peningkatan pengendalian surat yang akan dilakukan.

\section{Peningkatan pengendalian surat dengan sistem manual}

Peningkatan pengendalian surat dengan sistem manual terdiri dari hal-hal sebagai berikut: 


\section{a. Evaluasi SOP atau prosedur pengelolaan surat dengan sistem manual}

Pencatatan surat dapat diterapkan secara terpusat oleh sekretariat pusat, tetapi supaya adminsitrasi satuan kerja dapat melakukan pencatatan surat secara tersendiri untuk kepentingan satuan kerja maka lebih baik sekretariat pusat mengevaluasi SOP atau prosedur pengelolaan surat dengan sistem manual. Hal tersebut sangat berguna untuk dapat menjangkau pengelolaan surat di satuan kerja, sehingga output yang didapat yaitu distribusi surat jelas dan pencatatan surat jelas.

Selain itu dengan adanya pembaruan SOP atau prosedur pengelolaan surat dengan sistem manual, hal tersebut dapat menjadi reminder bagi para petugas pengelola surat supaya setelah membuat surat keluar diharapkan dapat memberikan hard copy atau soft copy surat kepada sekretariat pusat sehingga pusat arsip di sekretariat pusat menjadi lengkap dan tidak menyulitkan pencarian arsip surat.

\section{b. Unit Geomin dapat menerapkan tanda tangan elektronik untuk atasan kedepannya}

Hal tersebut dikarenakan pada saat kondisi surat memiliki sifat yang sangat urgent untuk dikirim kepada pihak penerima, tetapi atasan yang berhak menandatangani surat sesuai dengan kode jabatan surat sedang tidak ada di tempat dalam waktu yang sangat lama, seperti: perjalanan dinas, cuti, dsb. Oleh karena itu, lebih baik Unit Geomin dapat menerapkan tanda tangan elektronik untuk atasan. Hal tersebut dapat membuat waktu sekretariat pusat dan administrasi satuan kerja dalam mengelola surat menjadi efektif dan efisien, tetapi evidence sebagai tanda absah dari surat tersebut perlu dipertimbangkan dalam hal ini.

\section{c. Peningkatan pengendalian surat dengan sistem manual kedepannya dapat dilakukan menjadi sistem online}

Jika ditinjau dari sistem pencatatan surat dengan menggunakan program Microsoft Access, maka akses tersebut hanya dimiliki oleh sekretariat pusat, sedangkan jika diterapkan menjadi sistem online semua satuan kerja dapat melihat terkait pencatatan surat. Selain itu, dengan adanya sistem online para administrasi satuan kerja tidak perlu repot untuk meminta nomor surat kepada sekretariat pusat, tetapi administrasi satuan kerja dapat mengakses permintaan nomor surat sendiri dalam sistem online tersebut, sehingga dapat membuat pengelolaan surat menjadi lebih efektif dan efisien.

\section{Peningkatan pengendalian surat dengan sistem nota dinas online}

Peningkatan pengendalian surat dengan sistem nota dinas online yakni akan dilakukan beberapa hal yaitu: meningkatkan kinerja ICT secara terusmenerus supaya dapat melakukan maintenance jaringan internet, penambahan akses nota dinas online, serta maintenance dengan lebih cepat dan tidak menggangu para karyawan yang sedang bekerja.

Hal tersebut disebabkan karena sistem nota dinas online sangat tergantung pada jaringan internet dan akses yang dimiliki pegawai supaya dapat mengelola nota dinas.

\section{KESIMPULAN DAN SARAN}

\section{Kesimpulan}

1. Peningkatan pengendalian surat dalam pengelolaan surat dengan sistem manual di Unit Geomin dapat dilakukan dengan cara seperti: evaluasi SOP atau prosedur pengelolaan surat dengan sistem manual, menerapkan tanda tangan elektronik untuk atasan yang tidak sedang ada di kantor karena keperluan perjalanan dinas atau cuti yang sangat lama, dan meningkatan 
pengendalian surat dengan sistem manual kedepannya untuk dapat dijadikan sebagai pengelolaan surat dengan sistem online.

2. Peningkatan pengendalian surat dalam pengelolaan surat dengan sistem nota dinas online di Unit Geomin dapat dilakukan dalam beberapa hal yaitu: meningkatkan kinerja ICT secara terusmenerus supaya dapat melakukan maintenance jaringan internet, penambahan akses nota dinas online, serta maintenance dengan lebih cepat dan tidak menggangu para karyawan yang sedang bekerja. Hal tersebut disebabkan karena sistem nota dinas online sangat tergantung pada jaringan internet dan akses yang dimiliki pegawai supaya dapat mengelola nota dinas.

\section{Saran}

1. Hambatan yang muncul terjadi akibat pengelolaan surat yang tidak dikembangkan menjadi sistem yang lebih baik. Oleh karena itu, pengendalian surat sangat berperan penting dalam pengelolaan surat, karena hal tersebut dapat membantu untuk meminimalisir terjadinya suatu hambatan dalam pengelolaan surat di Unit Geomin.

2. Pengendalian surat di Unit Geomin dapat dilakukan sesuai dengan jangka waktu evaluasi sasaran mutu yakni setiap tahun, hal tersebut sangat bermanfaat karena jika terjadi hambatan dalam pengelolaan surat dapat ditangani secara cepat dengan cara pengendalian sesuai SOP perusahaan.

\section{UCAPAN TERIMA KASIH}

Penulis mengucapkan terima kasih kepada Pusat Penelitian Pengabdian Masyarakat (P3M) Politeknik Negeri Jakarta yang telah memberikan dana Bantuan Tugas
Akhir Mahasiswa (BTAM) untuk pelaksanaan penelitian ini.

\section{DAFTAR PUSTAKA}

Sedianingsih, Farida Mustikawati, dan Nieke P. Soetanto. 2014. Teori dan Praktik Administrasi

Kesekretariatan. Cetakan 2. Jakarta: Kencana.

Ummah, Evada El. 2017. "Pengurusan dan Pengedalian Surat dalam Kesekretariatan.” (http://administrasibisnis.com/2017/ 05/30/pengurusan-danpengendalian-surat-dalamkesekretariatan/ diakses 30 Mei 2017)

PT Aneka Tambang (Persero) Tbk. 2009. Pedoman Tata Persuratan Dinas dan Kearsipan PT ANTAM Tbk. Jakarta. 